\title{
THE APOTHECARIES' ACT, 1815: A REINTERPRETATION
}

by

\author{
S. W. F. HOLLOWAY
}

\section{PART II: THE CONSEQUENCES OF THE ACT}

THE Apothecaries' Act of 1815 bore the unmistakable marks of its origin. ${ }^{1}$ Based on James I's charter to the Apothecaries' Company, it drew heavily upon sixteenth and seventeenth century precedents both in phraseology and in ideology. Permeated by the influence of the College of Physicians, the Act has a closer affinity to a Stuart patent of monopoly than to a statute in the age of 'laissez-faire'. The avowed purpose of the Act was to ensure the better regulation of apothecaries throughout England and Wales by placing them under the supervision of the London Society of Apothecaries: its real function, however, was to maintain the ancient hierarchical structure of the medical profession and the apothecary's inferior status within it. Although the Apothecaries' Company sponsored the bill, and stood to gain most from its enactment, the Company was taken by surprise at the great augmentation of its powers. 'They had not prepared their minds', observed George Mann Burrows in 1834, 'for the extensive privileges which that Act gave them'. ${ }^{2}$ Few people, indeed, appear to have been aware of the real significance of the statute. It contained several obscure and loosely drawn clauses, the meaning of which only became clear after half-acentury of legal decisions.

Although the Act purported to be concerned with the regulation of the practice of apothecaries, it contained no clear definition of their functions and duties. Yet such a definition was essential to the enforcement of the Act. Unless it was known what constituted practising as an apothecary it would be impossible to initiate proceedings against the unqualified. Moreover, those practitioners who were able to prove that they had acted as apothecaries on 1 August 1815 were exempt from the operation of the penal clauses of the statute. But what was an apothecary? What were his duties and functions? These crucial questions were left to be answered by the Law Courts.

The only guidance that the Apothecaries' Act itself gave on this vital problem was contained in the fifth clause, a clause which had been inserted at the express command of the College of Physicians. This section stated that it is the duty of every person using or exercising the art and mystery of an apothecary to prepare with exactness and to dispense such medicines as may be directed for the sick by any physician lawfully licensed'. ${ }^{3}$ The Lancet, in 1826, argued that since the 1815 Act defined the apothecary as 'a mere retailer of simples, and the unpaid compounder of physician's

1 The following abbreviations are used throughout this article:

S.C.M.E. Select Committee on Medical Education, 1834.

B.P.P. British Parliamentary Papers.

S.C.M.E., 1834 (602-III) Part III, Q.269, p. 17.

The Statutes : Revised Edition, 1812-1823 (1874), Vol. V, p. 439. 


\title{
S. W. F. Holloway
}

prescriptions', the Apothecaries' Company could not prosecute practitioners for attending the sick and supplying medicines to them. It asked:

\begin{abstract}
What clause is there in the Apothecaries Act to render any man liable to a penalty for attending a patient, prescribing for a patient, and even dispensing the prescribed medicine? we answerNONE: prescribing for a patient and even dispensing the prescription and charging for the medicine, unless the prescriber be fool enough to style himself APOTHECARY, . . . we fearlessly contend is no offence under the Apothecaries Act; in no part of the Act is it stated to be such ... Not a single word is said about attendance on the sick, not a word said about prescribing, but on the contrary, the occupation of the Apothecary is specified to be that of retailing simples and compounding the prescriptions of 'legally authorised physicians', and yet the Worshipful Company have had the effrontery to found their prosecutions on the fact of attendance on the sick ... There is not the shadow of a foundation to be met with in the Act, which can justify the prosecutions instituted by the Worshipful Company-attending and prescribing for the sick are not once alluded to as forming parts of an Apothecary's duties."
\end{abstract}

This restricted interpretation of the 1815 Act was both logical and valid. But it was not the view of the Apothecaries' Society, nor did it receive support from the Law Courts. The judges interpreted the fifth clause of the Act in a most paradoxical manner. In 1819 it was held that since a farrier had never made up physicians' prescriptions, he could not claim to have been in practice before the passing of the Act; $;$ and nine years later Lord Tenterden agreed that unless there was evidence that a person had compounded physicians' prescriptions it could not be argued that he had practised as an apothecary. ${ }^{6}$ This seemed to be in accord with the Lancet's views. Nonetheless, in 1833, Justice Parke stated that 'it is not to be inferred . . . that if a person compounds medicine without being able to make up a physician's prescription, he is not liable to penalties for practising as an apothecary'. ${ }^{7}$ It was now ruled that a person who advises patients, and compounds and sells the medicines recommended by himself but does not and cannot make up physicians' prescriptions, is liable to the penalties of the 1815 Act for acting as an apothecary. ${ }^{8} \mathrm{~A}$ year later Justice Williams put forward a much extended definition of the apothecary's functions; an apothecary, he decided, was a practitioner who mixed and prepared medicines prescribed by a physician, or by any other person, or by the apothecary himself. ${ }^{9}$ By 1834 Justice Cresswell felt justified in defining an apothecary as 'one who professes to judge of internal disease by its symptoms and applies himself to cure that disease by medicine.'10

The Law Courts had imposed upon the 1815 Act a much wider interpretation than that suggested by the Lancet. It was an interpretation which had widespread repercussions. A correspondent of the Companion to the Newspaper admirably explained the consequences of this interpretation of the Apothecaries' Act:

The act in question was passed in the year 1815 and is entitled, 'An Act for better regulating the practice of Apothecaries throughout England and Wales' . . . Though Apothecaries is the term employed here and elsewhere, ... the persons whom the act affects are, with few exceptions,

Lancet, 1826, 10, 594-95.

'Apothecaries' Co. v. Warburton, 3B and Ald. 40.

- Thompson v. Lewis, 3 Car and P. 483; M and M. 255.

7 Apothecaries' Co. v. Allen, 4B and Ad. 627.

8 Ibid., 4B and Ad. 625-627.

- Woodward v. Ball, 6 Car and P. 577.

10 Apothecaries' Co. v. Lotinga, 2 Mood. and R. 499. 


\title{
The Apothecaries' Act, 1815: A Reinterpretation
}

the whole body of medical practitioners throughout the kingdom. In London, and some of our other great towns, there are physicians and surgeons who do not compound or vend medicines; but in the country this distinction of the three branches of the profession does not exist. Except in a few of our largest towns, every man who practises medicine at all, likewise deals in drugs, and must do so, unless he should undertake, in the treatment of his patients, to dispense with the materia medica altogether, or to cure them by making them swallow the written prescription itself, instead of the actual powders, draughts, and boluses. If he were not to supply them with medicines, there is nobody else from whom they could procure them.

The consequence is ... that over all England the medical practitioners are also apothecaries, within the meaning of this act. The exceptions are to be found only in the metropolis, and a few of our other largest towns. But even in the metropolis, probably nine-tenths of the practice is in the hands of persons who dispense drugs as well as advice and attendance.

Now, by this act, all these persons, constituting as they do all but the entire medical profession throughout England, must, in the first place, be Licentiates of the Apothecaries' Company. ${ }^{11}$

The same point was made in the Report of the Royal Commission of Inquiry into the state of the Universities of Scotland in 1831.

\begin{abstract}
Although the Act [of 1815] apparently only confers on the Company [of Apothecaries] the privilege of licensing Apothecaries, it has been stated to us, upon unquestionable authority, that under this denomination are included nine-tenths of the country practitioners in England. It is only in large towns, and probably rarely even in them, that the different departments of the Physician, Surgeon, and Apothecary, are kept separate: generally throughout the country it is necessary for every practitioner to dispense drugs. Hence the statute really confers upon the Apothecaries' Company the monopoly of licensing all the general practitioners in England and Wales. ${ }^{12}$
\end{abstract}

As a result of the judges' interpretation of the 1815 Act all those who wished to engage legally in general practice in England and Wales were obliged to become licentiates of the Society of Apothecaries. This, in itself, aroused great resentment among the rank and file of the profession. While the consulting physician and surgeon could claim to be members of Royal Colleges, the general practitioner was associated by law with a London trading company. One observer remarked:

It does not seem quite so reasonable, that, because the apothecaries have ceased to be grocers, they should be forthwith invested with the entire regulation of the practice of medicine in England.

A mercantile company originally instituted for the sale of certain commodities, and whose chief business that still continues to be, would not seem to be the fittest authority to which to confide the superintendence of one of the liberal professions, and the power of saying who shall, and who shall not, be permitted to enter it. Even if we had no colleges and universities where medicine was taught as a science, and no incorporated societies of the practitioners of its higher branches, it would seem to be sufficiently absurd to give the right of licensing its practitioners to the Company of Apothecaries. Better to demand as a qualification the diploma of some foreign school, or to institute a new board for the trial and examination of applicants. Nor, if the Apothecaries' Company were a great public establishment, instead of a mere private incorporation, and were regulated in regard to all its arrangements by some certain rules from which it could not depart, instead of being entitled to make for itself what by-laws and other regulations it pleases, would it still have any rational claim to be placed at the head of our national medicine. ${ }^{13}$

${ }^{11}$ The Companion to the Newspaper; and Journal of Facts in Politics, Statistics, and Public Economy. August 1833, p. 119.

${ }_{12}$ Report by a Royal Commission of Inquiry into the State of the Universities of Scotland (1831), (310) XII, p. 66.

${ }_{13}$ The Companion to the Newspaper, August 1833, pp. 119-120. 


\section{S. W. F. Holloway}

John Davies, physician to the Hertford General Infirmary, thought that the Apothecaries' Act was 'faulty in principle', and pointed out that it 'has always been regarded with great dislike by the profession'. The reasons for this were clear. 'Owing to the Executive under the Act being essentially a trading body, the certificate of the company has never been looked upon with respect by general practitioners. They are obliged, in a measure, to procure it, but it always 'went against the grain' to do so'. ${ }^{14}$ The surgeons and apothecaries of Scarborough in Yorkshire pertinently asked, 'What dignity or propriety is there in a Society as much allied to commerce as to medicine, thus dictating the mode of education of the whole practitioners of England according to its own narrow view?'15 And George Stansfield, in 1856, noticed the reluctance of practitioners to be regarded as members of the Apothecaries' Society. 'In many instances', he said, 'I have found that surgeons, though possessing the Apothecaries' licence, seem to be ashamed of it, as they have not returned themselves as such' in the Medical Directory. ${ }^{16}$

But the Apothecaries' Act not only insisted that everyone who practised medicine generally in England and Wales must possess the licence of the Apothecaries' Company. By another clause of the Act it was provided that no person could even be examined for the licence unless he had served an apprenticeship of not less than five years. This provision carried with it the implication that the general practitioner was a tradesman, not a member of a learned profession. It also meant the waste of precious years better devoted to secondary education. 'Under the enactment of this law', wrote John Davies, 'the pupil is placed upon a wrong career at his first step. Instead of being allowed to expand his mind by the acquisition of classical and general knowledge until about 18 or 19 years of age, he is, from the age of 14 or 15, immured for five years behind the counter, to acquire a knowledge which he might obtain easily in six months, at a later period, without any interference, at the same time, with his professional studies'. ${ }^{17}$ Another writer observed: 'Of course, every medical practitioner who finds it necessary to be the dispenser of drugs to his patients ought to have acquired the habit of distinguishing and measuring, and mixing the various articles of the materia medica. But to pretend that this cannot be done without standing behind a counter for five years, is nonsense. One year, not five, is all that is necessary. ${ }^{\text {18 }}$

The Scottish Universities' Commission in 1831 considered apprenticeships to be 'more frequently the nurseries of idleness and ignorance, than of industry and knowledge'. ${ }^{19}$ And 54 physicians and surgeons practising in Aberdeen found it difficult to conceive 'why young men should be obliged to pay a large fee, and to perform the menial offices of an Apothecary's apprentice for a period of five years, in return for advantages which a great number of them, at least, would obtain on much easier terms but for this interference of the Legislature'. 'Even in the most favourable

\footnotetext{
14 John DAvIES, M.D., An Exposition of the Laws which relate to the Medical Profession in England, 1844, p. 64.

${ }_{13}$ Reports from the Select Committee on Public Petitions, 1833, Appendix 296, p. 251.

16 Association Medical Journal, New Series, Vol. 4, 29 March 1856, p. 254.

17 JoHN DAvIES, M.D., op. cit., pp. 64-65.

${ }^{18}$ The Companion to the Newspaper, August 1833, p. 120.

10 Report by a Royal Commission of Inquiry into the State of the Universities of Scotland, 1831 (310) XII, p. 67.
} 


\section{The Apothecaries' Act, 1815: A Reinterpretation}

circumstances, therefore, where an apprenticeship may be supposed calculated to promote a young man's medical studies', they continued, 'the arrangement made in the Apothecaries' Act is obviously one in which the interests of those who are in training to the profession are sacrificed to the interests of those who are already engaged in practice'. ${ }^{20}$ Apprenticeship was, more often than not, a means by which apothecaries obtained unqualified assistants on highly favourable terms.

Quite apart from the effects on medical education, however, the apprenticeship clause had more immediate consequences for those already in general practice. In a memorandum submitted to a Select Committee of the House of Commons in 1833, G. J. Guthrie, President of the Royal College of Surgeons, outlined the harmful results of the 1815 Act:

1. By the old Apothecaries' Act, no doctor in medicine of any University can practice as an apothecary in England or Wales, unless he has been examined and approved of by the Society of Apothecaries of London; and when he presents himself for examination, he is told he cannot be examined, unless he has been for five years an apprentice to an apothecary; which it is more than probable he has not; and thus, although a more highly educated and competent man, he is, by this oppressive and tyrannical Act, precluded from getting his bread, whatever country he may be of. He cannot get it in his native village, if he be an Englishman or a Welshman, without being prosecuted for it as an offence.

2. By this same Act, a surgeon, however highly educated, or competent he may be, to act as an apothecary, cannot do so, unless he has been apprenticed to an apothecary in a similar manner: and whilst the physician and surgeon, of the highest possible attainments, are thus treated by the Apothecaries' Society, like toads under a harrow, the Master and all the Society of Apothecaries who have prosecuted these physicians and surgeons to their ruin ... for making up a pill, necessary after an operation, may, if they please, physic the same person to death; do the same operation, if they have not killed him before; and make up the same pill with perfect impunity. ${ }^{21}$

The chief sufferers from the 1815 Act were the Scottish trained physicians, many of whom had established themselves as general practitioners, particularly in the North and the Midland areas of England. The Royal Commissioners, whose report on the state of the Scottish Universities was published in 1831, drew attention to this fact.

The result of the operation of this statute is to exclude the whole Graduates of the Scottish Universities from practising in England unless they have served the requisite apprenticeship. It humbly appears to us, that while this regulation is most unjust in its consequences to the graduates of the Scottish universities, and inconsistent with the privileges which ought to belong to the universities of one part of the United Kingdom, it is at the same time most injurious to the interests of the community, by tending to exclude those who are best educated by preparatory and professional knowledge for the Medical Profession, from becoming general practitioners in England. It would be absurd to compare for a moment the education prescribed for the medical Graduates of the Universities of Edinburgh and Glasgow, with the requisites exacted from the persons licensed by the Apothecaries' Company. The direct effect of the enactment is to vest the monopoly of practice in a class of persons of very inferior education. ${ }^{22}$

In 1833 the medical practitioners of Manchester presented a petition to Parliament urging the Legislature to repeal the Apothecaries' Act, which imposes 'restraints of

20 Reports from the Select Committee on Public Petitions, 1833, Appendix 737, p. 827.

21 S.C.M.E., 1834 (602-II) XIII, Part II, Q.4944, p. 48: Memorandum submitted to the Select Committee of the House of Commons on the Apothecaries' Bill. By An Old Apothecary, pp. 48-50.

${ }^{22}$ Report by a Royal Commission of Inquiry into the State of the Universities of Scotland, 1831 (310) XII, pp. 66-67. 


\section{S. W. F. Holloway}

the most unjust, oppressive, and vexatious nature . . . upon every Medical Practitioner exercising his calling in England and Wales with a Scotch medical and surgical diploma'. Their petition listed in full the grievances of the Scottish-trained medical men:

1. No Scotch Practitioner, although he has obtained a Graduate's or Surgeon's Diploma, can dispense medicines in England or Wales, unless he has obtained the licence of the Apothecaries' Company, without subjecting himself to a penalty for each and every offence, excepting in cases purely chirurgical, and which constitute but a small share of diseases that come under his care as a general practitioner.

2. No Scotch Practitioner can sue in any Court of Law in England or Wales.

3. No Scotch Practitioner can legally act as Assistant to any Practitioner in England or Wales.

4. No Scotch Practitioner can accept the appointment of Apothecary to any hospital or dispensary in England or Wales.

4. [sic] No Scotch Practitioner can receive under his charge and tuition any young gentleman destined for a general Practitioner as an apprentice, as none are taken upon examination for the Company's diploma or licence, excepting those who have served a five years' apprenticeship to one of their licentiates.

6. [sic] A chemist and druggist who has received no medical education whatever, can prescribe, dispense, and compound medicines with impunity; whereas a Scotch Medical Practitioner, who has studied for four years, and been examined upon medicine, surgery, and pharmacy, is precluded from prescribing for any medical case, and is subject to a fine of $£ 20$ for compounding a single pill, draught or mixture.

7. Your Petitioners beg leave further to state to your honourable House, that every candidate for a Scotch medical or surgical diploma, is required to attend medical lectures for four academical seasons, embracing the full course of study prescribed by the Royal College of Surgeons in London, and the Worshipful Society of Apothecaries, for obtaining their respective diplomas; whereas the course of study prescribed for candidates for the license of the Apothecaries' Company can be completed in two academical seasons; and, further, candidates for a Scotch medical or surgical diploma are strictly examined upon medicine, surgery, and pharmacy, to ascertain their fitness and qualification to act as General Practitioners. ${ }^{28}$

This formidable list of grievances constituted a serious indictment of the Apothecaries' Act. For the Apothecaries' Society did not permit the Act to remain a dead letter. They employed the powers with which they were invested in 1815 in an attempt to make good their monopoly. In 1833 a Scottish physician was indicted and convicted under Section 20 of the 1815 Act for practising as an apothecary, and, on appeal, it was ruled that a person authorized to practise as a physician by a diploma from a Scottish university was not thereby exempt from the penal clauses of the Apothecaries' Act. ${ }^{24}$ Using this decision, the Society of Apothecaries sent threatening letters to Scottish licentiates insisting on their acquiring the Society's certificate. $^{25}$ Qualified surgeons were also made to feel the oppressive tendencies of the 1815 Act. In 1828 the judges decided that a person having a certificate from the College of Surgeons, but not licensed by the Apothecaries' Company, could not sue for medicine furnished to a patient suffering from typhus fever, which was considered to be a purely medical complaint. ${ }^{26}$ Similarly, in 1843 , it was ruled that although a surgeon might administer medicines in the cure of a surgical case, without being subject to the penalties of the Apothecaries' Act, he had no right to do so in

23 Reports from the Select Committee on Public Petitions, 1833, Appendix 652, pp. 698-99.

24 Apothecaries' Co. v. Collins, 4B and Ad. 604.

${ }_{25}$ Reports from the Select Committee on Public Petitions, 1833, Appendix 296, p. 251 ; and S.C.M.E., 1834 (602-III) Part III, Appendix 31, p. 141; and B.P.P., 1833 (435) XXXIV, p. 101.

26 Allison v. Haydon, 3 Car. and P. 246; 4 Bing. 619. 


\section{The Apothecaries' Act, 1815: A Reinterpretation}

the case of internal diseases not requiring surgical treatment, such as fever or consumption. ${ }^{27}$

The Apothecaries' Act proved a major obstacle to the improvement of the general practitioner's status. By the operation of 'the obnoxious apprenticeship clause', 28 such qualified doctors as the graduates of Scottish, Irish, and foreign universities and the members of the Royal Colleges of Surgeons were excluded from the legal practice of medicine in England and Wales. The Apothecaries' Company 'interrupted in the exercise of their profession, as general Practitioners, persons who by their medical knowledge and attainments, ascertained by examinations, and certified by diplomas, were fully qualified for their duty, and whose course of professional education was superior to what is required by the Company from their licentiates'.29 Only those who had served an apprenticeship of five years and had received the licence of 'the least celebrated medical corporation in the Empire'30 were permitted by law to perform the functions of the general practitioner. The Act, in short, tended 'to vest the monopoly of practice in a class of persons of very inferior education', and 'even to prevent the improvement of that class of practitioners who constitute the greater number of the medical profession throughout England' ${ }^{31}$ This was precisely the result foreseen by the College of Physicians when they agreed to the introduction of the Act, and when later they resolutely insisted upon the inclusion of the apprenticeship clause despite the desire of the Apothecaries' Company and the House of Commons to delete it. ${ }^{32}$ The College of Physicians had successfully diverted a movement, which sought to advance the status of the general practitioner, into an Act which chained him to the lowest order of the medical profession. A writer in 1834 summarized the effects of the 1815 Act in these words:

'The Physician may hold himself a little higher than the Surgeon, though both may be Baronets; ... . but the Apothecary, sheltered under the wings of both, neither doubts nor hesitates about his rank-he is the servant of all. ${ }^{33}$ In the eyes of the Royal College of Physicians this was exactly the consummation devoutly to be wished.

The inconsistencies and anomalies of the Act betray the haste and confusion with which it was conceived. The preamble of clause VII suggested that 'the great object of the statute ... was to prevent danger to the health and lives of the King's subjects by ignorant and incompetent practitioners' ${ }^{34}$ But the measure was singularly ill-adapted to serve that purpose. If it was indispensable to public safety that nobody should be

27 Apothecaries' Co. v. Lotinga, 2 Mood. and R. 495.

${ }^{28}$ Reports from the Select Committee on Public Petitions, 1833, Appendix 296, p. 251.

29 Ibid., Appendix 620, p. 645: cf. The petition from the Chancellor, Rector, and Principal and Professors of the University and King's College, Aberdeen. "The course of study followed in the medical schools of Edinburgh, Glasgow, and Aberdeen, under experienced teachers, is very far superior in extent and importance, to any course that has been or is at present required by the Company of Apothecaries..." Ibid., Appendix 778, p.880.

so Ibid., Appendix 296, p. 251.

81 Ibid., Appendix 582, p. 603.

${ }^{82}$ S.C.M.E., 1834 (602-III) Part III, Q.312, p. 21; The Quarterly Review, 67, December 1840, 64. The apprenticeship clause was struck out in the House of Commons but later inserted in the House of Lords.

${ }^{33}$ Observations on the Present System of Medical Education with a view to Medical Reform by a Licentiate of the Royal College of Physicians of London, 1834, p. 10.

${ }^{34}$ Apothecaries' Co. v. Roby (1822), 5B and Ald. 949. 
allowed to compound or vend medicines without serving a five years' apprenticeship to an apothecary, it is difficult to explain why people not qualified in this way were to be allowed to practise with impunity simply because they had been in practice on 1 August 1815. Only those apothecaries who could prove that they were in practice on that day were exempt from its provisions. Even a person who could show that he was practising as an apothecary before and on 12 July 1815, when the Act received the Royal assent, was liable to be prosecuted unless he had been licensed by the Society of Apothecaries. ${ }^{35}$ Moreover, if in justice to established practitioners, it was decided that they should have the benefit of this very limited exemption, regardless of the danger to the public health, it is hard to see why the exemption was not extended to those who had finished or even begun their professional education. Furthermore, if the five years' apprenticeship was considered to be an essential part of the education of general practitioners, upon what principle were the people of England and Wales alone to be protected? And why were university graduates and members of the Colleges of Surgeons allowed to indulge in general practice in Scotland, Ireland, and the colonies, and even admitted into the service of the East India Company, and into the medical departments of the Army and Navy?

Clause XXVIII of the 1815 Act provided 'that nothing in this Act contained shall extend or be construed to extend to prejudice or in any way to affect the trade or business of a chemist and druggist in the buying, preparing, compounding, dispensing, and vending drugs, medicines, and medicinable compounds, wholesale and retail; but all persons using or exercising the said trade or business, or who shall or may hereafter use or exercise the same, shall and may use, exercise, and carry on the same trade or business in such manner, and as fully and amply, to all intents and purposes, as the same trade or business was used, exercised, or carried on by chemists and druggists before the passing of this Act'. ${ }^{36}$ This clause had been inserted in order to ward off the opposition of the chemists and druggists. Yet it was well known that before 1815 the practice of the chemist and druggist was virtually indistinguishable from that of the apothecaries. 'Did he not dispense the prescriptions of LEGALLY AUTHORISED physicians?-did he not retail drugs? and more, did he not occasionally, nay frequently, visit and prescribe for patients? asked The Lancet in 1826 . 'It is notorious that he did', came the reply. ${ }^{37}$ For nearly thirty years after the passing of the Act the druggists were permitted to carry on their practice unmolested. But in 1841 a chemist was indicted and convicted for attending the sick and giving them medicines contrary to the provisions of the 1815 statute. ${ }^{38}$ Another thirty-five years elapsed before it was held that a chemist who suggested medicine, made it up, and sold it to customers who came to his shop asking him what was good for their ailments, was liable to penalties for practising as an apothecary. ${ }^{39}$

Although the Apothecaries' Act deterred many of the more highly qualified medical men in Britain from acting as general practitioners, it failed in its avowed purpose of preventing 'wholly ignorant and utterly incompetent' persons from endangering 'the

25 Ibid.

36 The Statutes : Revised Edition, 1812-1823 (1874), Vol. V, p. 446.

37 Lancet, 1826, 10, 595.

23 Apothecaries' Co. v. Greenough, 1. Q.B. 799; 11 L.J.Q.B. 156.

"Apothecaries' Co. v. Nottingham, 34 L.T. 76. 


\section{The Apothecaries' Act, 1815: A Reinterpretation}

health and lives of the community'.40 Between 1820 and 1832 the Society of Apothecaries prosecuted 86 people for practising as apothecaries in England and Wales without their licence. Even if all these cases had been directed against the unqualified, the effect would have been negligible. But, in fact, the Society was forced to select for prosecution, not the unqualified, but those practitioners against whom representations were made to the Company 'by individuals, necessarily partial, and generally actuated by motives of rivalry and private interest'.11 It was not the most equitable method of proceeding. Moreover, the process was both dilatory and expensive, mainly because the Society was obliged to prosecute in a court of record instead of before a magistrate. ${ }^{42}$ In a statement of self defence published by the Society after some thirty years' experience of the working of the Act, the following passage occurs:

The punishment [for unlicensed practice] being a penalty recovered only by action of debt which must be timed at the assizes for the county in which the offence is committed; the number of witnesses required to establish a conclusive case; the great expense necessarily attending the proceedings and the difficulty in most instances of obtaining sufficient evidence to warrant the adoption of proceedings, all combine to put it out of the Society's power to institute frequent prosecutions. ${ }^{43}$

There was a further difficulty. The endeavours of the Society to enforce the law were in very many instances frustrated, it was reported in 1833 , 'in consequence of the great unwillingness and backwardness in parties, when called upon, to furnish evidence or to come forward as witnesses in cases where information is given the Society respecting unqualified persons who are in practice as Apothecaries.' 44

John Davies, in 1844, doubted whether the protection extended by the 1815 Act 'has been of much service to practitioners in general . . . Against bone-setters, and other rural quacks and impudent pretenders, the law is, and has been, powerless. Although, in fact, they are numerous enough in every district, still it could not be proved to the satisfaction of a court of law, in one case out of five hundred, that they have been acting as 'apothecaries', according to the meaning of the statute'.45 Another writer observed, in 1840, that the Society of Apothecaries 'have frequently resorted to courts of justice in defence of their privileges, but with so little success that it is notorious that many apothecaries are practising without their licence, either in open defiance of the law, or (which is no difficult matter) contriving to evade it.'46

That there was a great deal of unqualified practice in Britain during the nineteenth century is beyond doubt. Although it is impossible to calculate exactly the total number of unqualified practitioners in England and Wales at any time during the century, some idea of their numbers can be obtained by comparing the total of

${ }^{40}$ The Statutes : Revised Edition, 1812-1823 (1874) Vol. V, p. 440.

11 The number of prosecutions is compiled from B.P.P., 1825 (232) XXI, p. 1 and 1833 (435) XXXIV, p. 99. See also S.C.M.E., 1834 (602-III) Part III, Appendix 12, pp. 105-108. The quotation is from George Mann Burrows' evidence in S.C.M.E., 1834 (602-III) Part III, Q. 285, p. 19.

is S.C.M.E., 1834 (602-III) Part III, Q. 178, p. 11.

is A Statement of the Society of Apothecaries on the subject of their Administration of the Apothecaries Act, 1844 , p. 30.

14 B.P.P., 1833 (435) XXXIV, p. 101.

45 JoHn DAVIES, M.D., op. cit., p. 65.

46 The Quarterly Review, December 1840, 67, 56. cf. Lancet, 1844, i, 51. 


\section{S. W. F. Holloway}

medical men reported in the Census returns with the number listed in the Medical Directory. For the Census returns, even after the establishment of the Medical Register in 1859, included both qualified and unqualified practitioners. ${ }^{47}$ According to the Census of 1851 there were in England and Wales 1,771 physicians, 13,470 surgeons, 10,846 druggists, and 2,228 unclassified medical men; a total of 28,315 . The total number of qualified practitioners in the same area according to the Medical Directory for the same year was only 10,130 . Although the figure of 18,185 unqualified practitioners is probably an over-estimate, it is clear that the penal clauses of the Apothecaries' Act had no appreciable effect in eliminating the unqualified or in protecting the qualified practitioners. This was admitted by the Society of Apothecaries in 1844 when it was acknowledged that 'there is no doubt that the number of unqualified persons who are at this time engaged in practice is very considerable. ${ }^{48}$

One of the major obstacles to the attainment of full professional status by the apothecary was the fact that he was permitted by law to charge only for medicines, not for attendance. This system led not only to his being considered a tradesmen in an age when trade was regarded as a debased occupation: it also exposed him to the accusation of over-charging and over-prescribing. The apothecary, it was said in 1703, 'makes the deluded Patient pay very extravagant Fees by the intolerable Prices he puts on all the cheap Medicines, and by passing upon him very many more Doses than the Disease requires or the Constitution can bear. ${ }^{49}$ Hence the custom arose for the apothecary on sending in his bill to leave a blank in which the patient inserted a sum of money which in his estimation would be a suitable remuneration for attendance. But since this amount was left entirely to the liberality of the patient, it could not be made the subject of a legal action unless there was an express agreement..$^{50}$ The leaders of the reform movement which preceded the passing of the Apothecaries' Act hoped that the statute would remedy this state of affairs. They were bitterly disappointed. Section 21 of the 1815 Act merely laid down that only licensed apothecaries would in future be allowed to recover charges in a court of law: it said nothing about remuneration for attendance. ${ }^{51}$ Miss Bernice Hamilton's statement that the Act gave the apothecary the 'right to charge fees for attendance, and a right to recover those fees at law if licensed, ${ }^{52}$ is an unjustified interpretation of clause 21 . The position was changed, not by the Apothecaries' Act, but by a series of legal decisions during the first half of the nineteenth century. The first step came in 1829 when Chief Justice Best, in Towne v. Gresley, held that an apothecary might charge for his attendance, provided he made no charge for the medicines furnished..$^{53}$ But

\footnotetext{
47 This apparently was not realised by Professor Arvel B. Erickson in his book The Public Career of Sir James Graham, Oxford, 1952, pp. 243-44.

${ }_{48}$ A Statement of the Society of Apothecaries on the subject of their Administration of the Apothecaries Act, 1844, p. 31.

${ }^{40}$ R. PITr, The Crafts and Frauds of Physic Expos'd, 1703, preface.

${ }^{50}$ H. Julian Fuller, 'Old $Q$ ' and the Apothecary (Privately printed, 1913), pp. 11, 28-29: and The Gentleman's Magazine, Vol. lxxxi, part ii, p. 8.

${ }_{51}$ The Statutes : Revised Edition, 1812-1823 (1874), Vol. V, p. 444.

52 Bernice HAMmton, 'The Medical Professions in the Eighteenth Century', Economic History Review, Second Series, 1951, 4, 168.

${ }_{58}$ Towne v. Gresley, $3 \mathrm{C}$ and P. 581. See also the comments on this case in The English Reports, Vol. CLXXII, Nisi Prius III, pp. 555-556.
} 
The Apothecaries' Act, 1815: A Reinterpretation

in the following year Lord Tenterden ruled that an apothecary might recover for reasonable attendance as well as for medicines. ${ }^{54}$ This decision was enthusiastically received by The Lancet. The editorial of 16 January 1830 stated:

General practitioners have been raised a thousand degrees in the scale of professional usefulness and respectability, and ten thousand degrees in the estimation of society. Rivers of mixtures and draughts, mountains of pills, boluses, and plasters, at once vanish before the decree of this acute and venerable judge ... General practitioners will no longer be regarded in families, as plunderers, whose interested object is to convert the stomachs of their patients into drug-shops but they will now be looked upon as men of experience and skill, and their ability to prescribe appropriate remedies for disease, will be valued rather more highly than the ability to mix those remedies in a bottle, or in a mortar. ${ }^{.55}$

Lord Tenterden's decision was confirmed in 1838 by Justice Littledale, who asserted that there was no rule of law precluding an apothecary from recovering both for medicines and attendance, where the joint charges do not exceed a reasonable remuneration. ${ }^{56}$ This was certainly an important factor in raising the status of the apothecary; but its usefulness was limited by the operation of the Apothecaries' Act, which prevented Scottish-trained medical men and members of the Colleges of Surgeons from benefiting from these decisions.

In the light of this analysis of the Apothecaries' Act it is difficult to agree with the current interpretation of that statute. A. M. Carr-Saunders and P. A. Wilson, in 1933, wrote that it would not be astonishing to find 'this remarkable Act' among the accomplishments of the reformed Parliament, "but it stands somewhat isolated in the legislation of the preceding period'. ${ }^{57}$ Dr. F. N. L. Poynter also saw the Act as a triumph for reform. 'The Act of 1815', he stated, 'by which apothecaries gained the legal sanction to practise medicine, ${ }^{58}$ was the first triumph for the reforming spirit which was clearly at work among them even in the first decade of the nineteenth century. "Liberty, Equality, Fraternity" was the slogan of a nation with whom we were at war, but to many Englishmen it was none the worse for that'. ${ }^{59}$ Miss Bernice Hamilton, who is more temperate in her praise, believed that 'the Act did an immense amount of good', ${ }^{60}$ and for W. J. Bishop it ranks as 'the great landmark in the history of the general practitioner'. ${ }^{61}$ Professor W. H. G. Armytage regarded the statute as 'one of the most significant of the century', ${ }^{62}$ while for Dr. Newman its passing marks 'the zenith of the apothecary in history'. ${ }^{63}$ Contemporaries, however, were by no means so impressed. The Lancet held that the Act 'was framed with an eye to the immediate advantage of a few, to the obvious injury of thousands, and that instead

${ }^{54}$ Handey v. Henson, 4 Car. and P. 110.

${ }^{55}$ Lancet, 1829-30, i, 538.

so Morgan v. Hallen, 8A and E 489.

57 A. M. CarR-Saunders and P. A. Wilson, The Professions, Oxford, 1933, p. 78.

58 The apothecaries gained the legal sanction to practise medicine in 1703 as a result of the decision of the House of Lords in the College of Physicians v. Rose, for which see J. W. Willcock, The Laws relating to the Medical Profession, 1830, pp. xciii-xcvi.

${ }^{59}$ F. N. L. PoYnTER, 'The Centenary of the General Medical Council', Brit. med. J., 1958, ii, 1245.

${ }^{60}$ Bernice Hamilton, op. cit., p. 168.

61 W. J. Bishop, 'The Evolution of the General Practitioner', Science Medicine and History, Essays ... written in honour of Charles Singer, Collected and edited by E. Ashworth Underwood, London, Oxford University Press, 1953, Vol. II, p. 354.

${ }^{62}$ W. H. G. ARMYTAGE, Civic Universities, 1955, p. 169.

as Charles Newman, The Evolution of Medical Education in the Nineteenth Century, Oxford, 1957, p. 77. 


\section{S. W. F. Holloway}

of its being of a beneficial nature, either to the public or exclusively to the Members of the Medical Profession, it was only calculated to retard the progress of the most useful of all sciences, and to fill the coffers of a herd of ignorant pharmacopolists'. ${ }^{64}$ 'It was projected by avarice, supported by intrigue, and enacted by ignorance', said the journal on another occasion. ${ }^{65}$ One commentator regarded the Act as "one of the most impudent pieces of legislation that have been perpetrated in modern times'. 'We do not recollect', he continued, 'any other statute passed since the commencement of the present century, the injustice and absurdity of which have been at the same time so sweeping and so scandalous'.66

Although the language is vitriolic, these contemporary opinions may well be nearer the truth than the judgments of present-day historians. The 1815 Act sought to perpetuate the obsolete hierarchical structure of the medical profession; it placed the general practitioner under the supervision of a London mercantile company and tied him to a system of education more suited to a trade than to a liberal profession; it failed to protect him from the competition of the unqualified and did nothing to change the degrading system by which he was remunerated; above all, it deterred many of the more highly qualified members of the profession from acting as general practitioners.

It has been argued that 'one very important result of the Act was to bring into being a system of medical education' ${ }^{67}$ A. M. Carr-Saunders and P. A. Wilson, Professor Armytage, and Sir Zachary Cope, ${ }^{68}$ all relate the growth of medical schools, both in London and the provinces to the stimulus afforded by the Apothecaries' Act. The arguments that have been put forward by these scholars to show that the Apothecaries' Act created a system of medical education in England can best be summarized as two propositions. First the apparently disinterested and efficient manner in which the Society of Apothecaries administered the Act has been regarded as the most important, even the sole, factor influencing the development of medical education during the period 1815-1858. Secondly, it is claimed that since the foundation of regular medical schools in London and the provinces dates from the period immediately after 1815 , the schools must therefore have been brought into existence by the Act to prepare candidates for the examinations of the Apothecaries' Company. These arguments are sufficiently important to merit detailed attention.

The main features in which the Society of Apothecaries were educationally successful can be briefly enumerated. In the first place they endeavoured to maintain a fair standard of general education. They insisted upon an elementary knowledge of Latin and would not begin the qualifying examination of a candidate unless they were satisfied in that respect. ${ }^{69}$ They were, nonetheless, rather easily satisfied and this preliminary requirement approached neither the high standard of general education expected at the Universities of Edinburgh and Glasgow, nor the rarefied heights of a degree in arts demanded by the College of Physicians. The apprenticeship clause of

is Lancet, 1826, 10, 625.

is Lancet, 1825-1826, 9, 5.

is The Companion to the Newspaper, August 1833, p. 119.

67 A. M. Carr-Saunders and P. A. Wilson, op. cit., p. 79.

os ZACHARY COPE, 'Influence of the Society of Apothecaries on Medical Education', Brit. med. J., $1956, \mathrm{i}, 1-6$

60' S.C.M.E., 1834 (602-III) Part III, Appendix 24, p. 124, and Appendix 28, pp. 127-34. 


\section{The Apothecaries' Act, 1815: A Reinterpretation}

the 1815 Act frustrated all the Society's attempts to raise the level of general education of the candidates for their diploma. 'The tendency of the apprenticeship', remarked one observer, 'is always to throw a great impediment in the way of obtaining a good general education: and in a great number of instances to prevent it altogether' ${ }^{70}$

When the Apothecaries' Act came into force the requirements which each candidate had to fulfil before he could enter for the qualifying examinations were, of necessity, somewhat elementary. The range of the examination and of the course of training, however, increased to keep pace with the rapidly advancing body of scientific knowledge. Additional subjects were added to the syllabus and the required courses of study were successively lengthened and multiplied. The regulations that came into force on 1 October 1835 compare favourably even with the curriculum of the Scottish universities. ${ }^{11}$

From 1815 to 1840 the examinations were oral only $;^{72}$ but they were generally regarded as fair, reasonably comprehensive, and appropriate. Sir David Barry, in 1834, went so far as to say 'that the examination established by the Company of Apothecaries is now by far the most comprehensive examination in London'.73 There were twelve examiners who met every Friday throughout the year and rarely were any of them absent. ${ }^{74}$ At first the number of candidates was under 200 per annum but later as many as $\mathbf{4 0 0}$ or 500 people annually faced the examiners. ${ }^{75}$ In the examination the examiners divided into groups of three. One of these was examiner-in-chief for any particular candidate, but the other two, if they wished, could also take part in the questioning. If the result of the examination by the group was satisfactory the candidate was passed, but, if unsatisfactory, then the examiners from other groups came over to take part in the examination, and no candidate was failed unless a majority of the total number of examiners agreed that he did not come up to the required standard. The time taken over the examination of each candidate was between an hour and a half, and an hour and three-quarters, and every subject in the curriculum was supposed to be dealt with during that time. ${ }^{76}$

The court of examiners was, moreover, wise enough to demand more than an examination test: certificates of attendance at hospitals, or dispensaries, and at lectures had to be produced by candidates. ${ }^{77} \mathrm{~A}$ high level of instruction was guaranteed by strict scrutiny of the qualifications of those who applied for the recognition of their courses of lectures, and by the careful inspection of the hospitals and schools both in London and in the provinces. ${ }^{78}$ In 1834 about 100 hospitals and 43 different schools had been approved by the Society. ${ }^{79}$ Nevertheless, the College of Surgeons set an even higher standard in its inspection and recognition of hospitals and medical

${ }^{70}$ The Quarterly Review, December 1840, 67, 65.

${ }_{71}$ S.C.M.E., 1834 (602-III) Part III, Appendix 24, pp. 120-24.

72 C. R. B. BARRETT, The History of the Society of Apothecaries of London, 1905, p. 220. Professor Armytage, and A. M. Carr-Saunders and P. A. Wilson would seem to be mistaken in asserting that the Apothecaries' examination was a written examination before 1840: see W. H. G. ARMYTAGE, op. cit., p. 169, and A. M. CARR-SAUNDERS and P. A. WILSON, op. cit., p. 79.

7s S.C.M.E., 1834 (602-I) XIII, Part 1, Q. 2583, p. 167; see also Q. 2599, p. 169.

74 S.C.M.E., 1834 (602-III) Part III, Appendix 17, p. 114, and Appendix 18, pp. 115-16.

75 Ibid., Appendix 7, p. 101.

78 Ibid., Q. 633, p. 46; and Q. 662, p. 49.

77 Ibid., Appendix 25, pp. 124-25.

${ }_{78}$ Ibid., Appendix 23, p. 120.

79 Ibid., Appendix 29, pp. 134-36, and Appendix 30, pp. 137-41. 


\section{S. W. F. Holloway}

schools. ${ }^{80}$ Nor were the regulations of the Apothecaries' Society as reasonable as has often been stated. When St. Mary's Hospital was opened in 1851 with 150 beds and a distinguished staff, it was at first refused recognition by the Society merely because there was no resident qualified apothecary. ${ }^{81}$ And when the medical courses were being arranged at University College London in 1828 the revolutionary, if grandiose, plan of instruction devised by the medical professors had to be modified to comply with the more conservative regulations of the Apothecaries' Company. ${ }^{82}$

In all their efforts to raise the standard of education of candidates for their licence, the Society was handicapped by the provisions of the 1815 Act. The apprenticeship clause, as we have already noticed, frustrated their efforts to raise the level of general education; and although they allowed time spent in hospital training to count as part of the period of apprenticeship, they were never able to increase the period to be spent at medical school which the advance of medical science and of society necessitated. The 1815 Act also limited the Society in its choice of examiners. Only members of the Company of ten years' standing were eligible for appointment. ${ }^{83}$ Membership was obtained either by patrimony or by purchase. ${ }^{84}$ Those who were only licentiates of the Society and all other members of the profession were thus excluded from the examining board. Whereas the College of Surgeons could boast that its examining body included many of the most eminent surgeons in the country, the examiners at Apothecaries' Hall were singularly undistinguished. 'By restricting themselves in the way they have done', remarked George Mann Burrows, who had himself been one of the Society's examiners, 'they have not had so good a court as they might have had'. ${ }^{85}$ There was a further anomaly. Although nearly every general practitioner engaged in midwifery, the Society had no power to examine candidates in it. The Society was anxious to institute such an examination, and most of the examiners at the Hall themselves practised midwifery. ${ }^{86}$ 'We ask candidates for testimonials of their having attended courses of midwifery, and we go as near to examining in midwifery as we can. We examine them upon the diseases of women and children, and up to the very point of labour', noted John Bacot, 'but there our examination ends; for the delivery of a woman is said to be a surgical operation' ${ }^{87}$ This was the reductio ad absurdum of the theory of orders.

In spite of all the difficulties, it is clear that the Society of Apothecaries set about putting the 1815 Act into operation with energy and good intentions; and, in 1834, the Presidents of the Royal College of Physicians and the Royal College of Surgeons paid generous tribute to the use which the Society had made of its powers. 'They have executed that Act extremely well', said Sir Henry Halford, 'the character of that branch of the profession has been amazingly raised since they have had that

${ }^{80}$ S.C.M.E., 1834 (602-II) XIII, Part II, Q. 4907, pp. 31-35; and Appendices 25, 26, 28, 29, 30, 33,34 , pp. $30-41,41-44,45-47,47-49,49-50,55-58,58-60$.

${ }^{81}$ ZACHARY COPE, The History of St. Mary's Hospital Medical School, 1954, p. 20.

82 C. R. B. BARRETt, op. cit., p. 201; H. HAle Bellot, University College London 1826-1926, 1929 , p. 145.

${ }_{83}$ S.C.M.E., 1834 (602-III) Part III, Q. 120, 121, p. 8.

84 Ibid., Q. 117, 118, 119, p. 8.

85 Ibid., Q. 279, p. 18.

86 Ibid., Q. 234-236, p. 15.

87 Ibid., Q. 424, p. 30. 


\section{The Apothecaries' Act, 1815: A Reinterpretation}

authority'.88 'I must declare ...,', remarked G. J. Guthrie, 'my sense of the admirable manner in which the Apothecaries Company have done their duty to the public' ${ }^{89}$ But does it necessarily follow that it was this work which led to the foundation of medical schools in London and the provinces? Are we justified in ascribing to the Society of Apothecaries the credit for raising the status of the general practitioner during the period 1815-1858? There are sound reasons for believing that such an argument is merely a repetition of the post hoc ergo propter hoc fallacy.

It has already been suggested that the Apothecaries' Act operated in a manner extremely detrimental to the status of the general practitioner. It has also been shown that the licence of the Apothecaries' Society was obtained by practitioners only under duress: they resented the fact that they were obliged by law to qualify in this way. The Royal College of Surgeons has at least an equal claim to be considered the force making for the advance of medical education. In the ten years between 1823 and 1833 the College of Surgeons attracted only 206 fewer candidates than the Society of Apothecaries. From 1 January 1823 to 31 December 1832, 4,189 students took the examination for the M.R.C.S.; between 1 August 1823 and 31 July 1833, 4,395 candidates faced the examiners at Apothecaries' Hall. ${ }^{90}$ Yet there was no legal necessity for practitioners to become members of the College of Surgeons. 'The London College of Surgeons', it was pointed out in 1840, 'have no monopoly, no privileges, no power to prosecute. Any one may establish himself as a surgeon, even next door to the college, and no one can molest him. But the College is of royal foundation, and the diploma which it grants has affixed to it the signatures of many of the leading surgeons of London: and so necessary has it become to any one who makes the least pretension to practise surgery, that there are few, either in England or in the colonies (with the exception of those who have a similar diploma from the Colleges of Dublin or Edinburgh), who venture to call themselves surgeons without it'. ${ }^{91}$ The same point was made by John Davies four years later. 'It has not been obligatory', he wrote, 'to pass the college [of surgeons]: they might practise with equal legality without possessing its Diploma: yet they have considered it, as a general rule, an essential point to obtain it, although the qualification requisite for that purpose has, up to a late period, been much higher than that required for the certificate of the Apothecaries' Company'. ${ }^{92}$ It would be equally legitimate to argue that the medical schools which were organized in the period after 1815 were established to prepare candidates for the examinations of the College of Surgeons as for those of the Apothecaries' Society.

There is little reason, therefore, to attribute the extension of medical education and the subsequent improvement in the status of the general practitioner solely, or even primarily, to the influence of the Society of Apothecaries and the College of

${ }^{88}$ S.C.M.E., 1834 (602-I) XIII, Part 1, Q. 219, p. 16.

89 S.C.M.E., 1834 (602-II) XIII, Part II, Q. 4943, p. 48.

${ }^{20}$ The figures for the Royal College of Surgeons are derived from B.P.P., 1833 (459) XXXIV, p. 117; those for the Society of Apothecaries are to be found in S.C.M.E., 1834 (602-III) Part III. Appendix 7, p. 101.

91 The Quarterly Review, December 1840, 67, 56.

92 JOHN DAVIES, M.D., op. cit., p. 80.

In 1845 the College itself reminded members 'that in applying for their diploma they were not compelled to do so by any legal enactment, as they would have had an equal right to practise surgery without it.' B.P.P., 1845 (271) XXXVI, p. 450. 


\section{S. W. F. Holloway}

Surgeons. The emergence of regular medical schools in London and the provinces was not the direct result of the raising of the standard of entry into the profession nor of the increased demands of the medical curriculum. These developments were merely symptoms of more fundamental and widely spread compulsions within the structure of society itself. They have to be seen as part of the totality of social change. But that story has been told elsewhere. ${ }^{93}$

93 S. W. F. HollowaY, 'Medical Education in England, 1830-1858: A Sociological Analysis', History, 1964, 49, 299-324. 